\title{
CHARACTERISTICS OF THE HEAT BALANCE OF THE GREENLAND ICE SHEET FOR MODELLING
}

\author{
By W. Амвасн
}

(Institut für Medizinische Physik, Müllerstrasse 44, A-6020 Innsbruck, Austria)

\begin{abstract}
Data of the heat balance measured during EGIG 1959 and 1967 are applied to calculate the shift in equilibrium line due to climatic changes. The analysis follows Kuhn's algorithm by determining from the data: (i) response of the net radiation balance due to changes in air temperature, cloudiness, and albedo, (ii) the response of the sensible heat flux due to changes in air temperature, (iii) the altitudinal gradients of air temperature and cumulative accumulation, (iv) the duration of the ablation season, and ( $v)$ the significance of superimposed ice. The shift of the equilibrium line due to changes in cloudiness is negligible compared to that which is caused by changes in temperature. The formation of superimposed ice, however, influences the result considerably. The shift of the equilibrium line amounts to $+77 \mathrm{~m} \mathrm{~K}^{-1}$ at constant cloudiness and $-4 \mathrm{~m}$ per $1 / 10$ cloudiness at constant temperature.
\end{abstract}

RÉsumé. Caractéristiques du bilan thermique de la calotte du Groenland pour la modèlisation. Des données de bilan thermique récoltées au cours de l'EGIG de 1959 et 1967 sont appliquées au calcul du déplacement de la ligne d'équilibre dû au changement climatique. L'analyse suit l'algorithme de Kuhn qui détermine les relations suivantes à partir des données mesurées: (i) la réponse du bilan net de rayonnement causé par des variations de température de l'air, nébulosité et albedo, (ii) la réponse du flux de chaleur sensible dû aux changements de la température de l'air, (iii) les gradients altitudinaux de température de l'air et d'accumulation cumulée, (iv) la durée de la saison d'ablation, et (v) la signification de la glace surimposée.

\section{INTRODUCTION}

Surface melting shares considerably in the mass balance of the Greenland ice sheet (Bauer, 1955; Weidick, 1975; Radok and others, 1982), which therefore reacts very sensitively to fluctuations in climate (Ambach, 1980). Heat-balance data therefore provide a deeper insight into the relations between climatic disturbances and changes of the mass balance.

Kuhn's concept allows the shift of the equilibrium line to be calculated in correlation to small climatic changes [Kuhn, 1981]). The algorithm proposed involves parameters which can be determined from heat and mass balance studies. The algorithm has already been applied to positions of the equilibrium line in the Alps and in the Andes (Kuhn, $1980,[1982])$.

During the International Glaciological Greenland Expedition (EGIG 1959 and 1967) detailed heat and mass balance studies were carried out in the area of ablation and accumulation (Ambach, 1963, 1977[a], [b]; Ambach and Mark1, 1983). In the present paper, results on Kuhn's algorithm are discussed in order to estimate the response of the equilibrium line at the EGIG profile to small climatic disturbances. The following are investigated in detail:

(i) the response of the net radiation balance to changes in air temperature, cloudiness, and albedo,

(ii) the response of the sensible heat flux to changes of the air temperature,

(iii) the altitudinal gradients of the air temperature and of the cumulative accumulation,

(iv) the duration of the ablation season, and

(v) the significance of the formation of superimposed ice.
Le déplacement de la ligne d'equilibre du aux variations de nébulosité est négligeable en regard de celui causé par les variations de température. Cependant la formation de glace surimposée influence considérablement le résultat. Le déplacement de la ligne d'équilibre vaut $+77 \mathrm{~m} \mathrm{~K}^{-1}$ à nébulosité constante et $-4 \mathrm{~m}$ par $1 / 10$ de nébulositê à température constante.

Zusammenfassung. Charakteristiken des Wärmehaushaltes des grönländischen Inlandeises zur Modellbildung. Messdaten des Wärmehaushaltes, die während der EGIG 1959 und 1967 gewonnen wurden, werden zur Berechnung der Verschiebung der Gleichgewichtslinie bei einer Klimaänderung herangezogen. Die Analyse wird nach dem Kuhn'schen Algorithmus durchgeführt. Dazu müssen folgende Beziehungen aus den Messdaten bestimm werden: (i) die Änderung der Nettostrahlungsbilanz durch Änderungen der Temperatur, der Bewölkung und der Albedo, (ii) die Änderung des fühlbaren Wärmestromes durch Änderung der Lufttemperatur, (iii) die Höhengradienten der Lufttemperatur und der kumulativen Akkumulation, (iv) die Dauer der Ablationsperiode, und (v) die Bedeutung der Bildung von superimposed ice. Die Verschiebung der Gleichgewichtslinie durch Bewölkungsänderung ist gegenüber jener durch Temperaturänderung vernachlässigbar. Die Bildung von superimposed ice beeinflusst jedoch das Ergebnis wesentlich. Als Höhenverschiebung der Gleichgewichtslinie erhält man $+77 \mathrm{~m} \mathrm{~K}^{-1}$ bei konstanter Bewölkung und $-4 \mathrm{~m}$ pro $1 / 10$ Bewölkung bei konstanter Temperatur.
The intention of the present paper is to analyse heat balance data measured at the EGIG profile for modelling according to Kuhn's algorithm.

\section{RADIATION FLUXES}

In connection with Kuhn's concept, the following relations are examined

(i) The numerical relation between changes in air temperature and changes in long-wave downward radiation. In this connection, results of measurements of long-wave radiation balance have been evaluated as a function of cloudiness (section 2.1).

(ii) The dependence of the net radiation balance on the cloudiness and on the albedo. Results of measurements on snow surfaces and ice surfaces are used for this analysis (section 2.2).

2.1 Dependence of long-wave radiation balance on cloudiness

The dependence of the long-wave radiation balance on the cloudiness is used for calculating the relative emissivity of the atmosphere according to the Stefan-Boltzmann law. The long-wave downward radiation is given as

$$
A=\varepsilon+(w)_{\sigma} T_{a}{ }^{4}
$$

where $\varepsilon^{+}(w)$ is the relative emissivity at cloudiness $w, \sigma$ is the Stefan-Boltzmann constant, and $T_{a}$ is the actual air temperature valid for a representative radiation level. $\varepsilon^{+}(w)$ may be calculated as a function of cloudiness. Equation (1) gives a relation between temperature and long-wave downward radiation which is of significance for Kuhn's algorithm. 
The mean values of long-wave radiation balance LB as dependent on the cloudiness $w$ for the series measured during EGIG 1959 and EGIG 1967 may be represented approximately by the following functions (Ambach, 1963, p. 70, fig. 20; Ambach and Mark1, 1983 , p. 28, fig. 11):

$E G I G$ 1959:
$L B(w)=-4.00\left(1-0.70 w^{2}\right) M J / m^{2} d, \frac{0}{10}<w<\frac{10}{10}$,

EGIG 1967

$L B(w)=-6.00\left(1-w^{2}\right) M J / m^{2} d, \quad \frac{0}{10}<w<\frac{10}{10}$.

Fron these results a relative emissivity of the atmosphere $\varepsilon^{+}(w)$ is calculated

$$
L B(w)=\varepsilon^{+}(w) \sigma T_{a}^{4}-\varepsilon \sigma T_{0}^{4}
$$

where $\varepsilon^{+}(w)$ is a function of cloudiness. Assuming $\varepsilon^{+}(w)(10 / 10)=1$ and $\varepsilon=1$ for the surface $\left(T_{0}\right)$, we obtain

$$
\begin{aligned}
& \operatorname{LB}\left(\frac{10}{10}\right)=\sigma T_{a^{4}}-\sigma T_{0}^{4}, \\
& L B(w)=\varepsilon^{+}(w) \sigma T_{a}^{4}-\sigma T_{0}^{4}, \\
& \varepsilon^{+}(w)=\frac{L B(w)+\sigma T_{0}^{4}}{L B\left(\frac{10}{10}\right)+\sigma T_{0}^{4}} .
\end{aligned}
$$

Furthermore, a melting surface may be assumed for the ablation season so that the numerical values of $\varepsilon^{+}(w)$ can be calculated from the series measured in EGIG 1959 (Ambach, 1963, p. 70, fig. 20). A mean cloudiness of $w=5 / 10$ is assumed. According to Equation (2a), $\operatorname{LB}(5 / 10)=-3.30 \mathrm{MJ} \mathrm{m}^{-2} \mathrm{~d}^{-1}$ and $\operatorname{LB}(10 / 10)=$

$1.20 \mathrm{MJ} \mathrm{m}^{-2} \mathrm{~d}^{-1}$. With $\sigma \mathrm{T}_{0}^{4}=4.90 \times 10^{-3} \times 273.15^{4}=$

$27.3 \mathrm{MJ} \mathrm{m}^{-2} \mathrm{~d}^{-1}$ the value of 0.92 is thus obtained for $\varepsilon^{+}(5 / 10)$ according to Equation (3). An analogous evaluation of the EGIG 1967 series is not possible as the surface temperature cannot be assumed to be constant at the melting point.

The effect of an atmospheric temperature change $\delta \mathrm{T}_{\mathrm{a}}$ on the long-wave downward radiation $\delta \mathrm{A}$ may be calculated by the linearization

$$
\begin{aligned}
\delta A & =\alpha^{\prime} \delta T_{a}, \\
\alpha^{\prime} & =\varepsilon+\left(\frac{5}{10}\right) 4 \sigma T_{0}^{3}
\end{aligned}
$$

where $\alpha^{\prime}=0.37 \mathrm{MJ} / \mathrm{m}^{2} \mathrm{~d} \mathrm{~K} \mathrm{holds} \mathrm{for} \varepsilon^{+}(5 / 10)=0.92$ and $4 \sigma \mathrm{T}_{0}^{3}=0.40 \mathrm{MJ} \mathrm{m}^{-2} \mathrm{~d}^{-1} \mathrm{~K}^{-1}$.

It follows that

$$
\delta A=0.37 \delta T_{a} M J m^{-2} d^{-1} \text {. }
$$

Equation (5) expresses the relation between a temperature disturbance $\delta T_{a}$ and a change in long-wave downward radiation $\delta A$.

\subsection{Dependence of the net radiation balance on} cloudiness

The dependence of the net radiation balance on the cloudiness is mainly governed by the albedo. This means that periods of different albedo must be examined separately (Table I). The differences in net radiation balance between a cloudiness of $0 / 10$ and $10 / 10$, however, can be formuluated as a function of

TABLE I. DAILY MEAN VALUES OF NET RADIATION BALANCE FOR CLEAR SKY AND COVERED SKY FOR VARIOUS ALBEDO VALUES (Ambach, 1977[a], p. 22, Table 5; Ambach and Markl, 1983, p. 28)

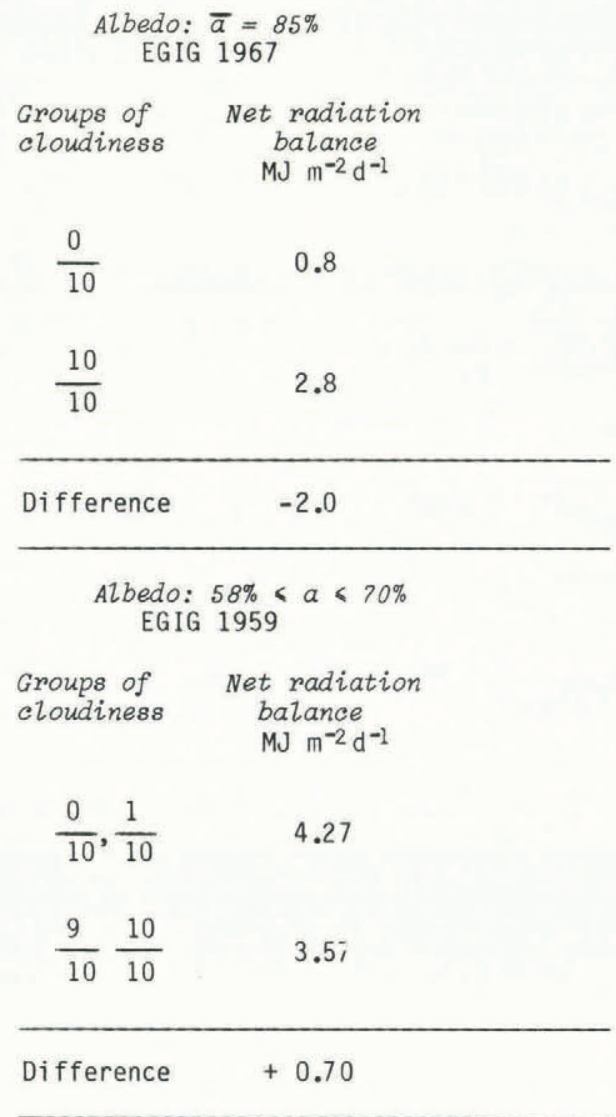

Albedo: $a>70 \%$

EGIG 1959

$\begin{array}{cc}\begin{array}{c}\text { Groups of } \\ \text { cloudiness }\end{array} & \begin{array}{r}\text { Net radiation } \\ \text { balance } \\ \text { MJ m } \mathrm{m}^{-2} \mathrm{~d}^{-1}\end{array} \\ \frac{0}{10}, \frac{1}{10} & 1.18 \\ \frac{9}{10}, \frac{10}{10} & 3.48\end{array}$

Difference $\quad-2.30$

Albedo: $a<58 \%$

EGIG 1959

Groups of Net radiation

cloudiness balance

MJ $\mathrm{m}^{-2} \mathrm{~d}^{-1}$

$$
\begin{aligned}
& \frac{0}{10}, \frac{1}{10} \\
& \frac{9}{10}, \frac{10}{10}
\end{aligned}
$$

Difference $\quad+\quad 2.76$


albedo only if the short-wave incoming radiation is nearly constant during the whole period of measurement. This holds approximately for the series measured in EGIG 1959 and in EGIG 1967, because the measurement periods are about symmetrical to the summer solstice. In an earlier paper it has been shown that a high albedo causes the daily sum of net radiation balance to increase as the cloudiness increases (Ambach, 1974). This effect is explained by the fact that the fluctuations in net radiation balance at high albedo due to the dependence on cloudiness are governed by the fluctuations in long-wave radiation balance. Short-wave radiation balance here plays a minor role. This phenomenon, typical of polar regions, is of great interest and has already been discussed in detail (Ambach, 1977[a], p. 31, fig. 15).

Figure 1 shows the difference in net radiation balance $\mathrm{NB}(0 / 10)-\mathrm{NB}(10 / 10)$ to be positive at low

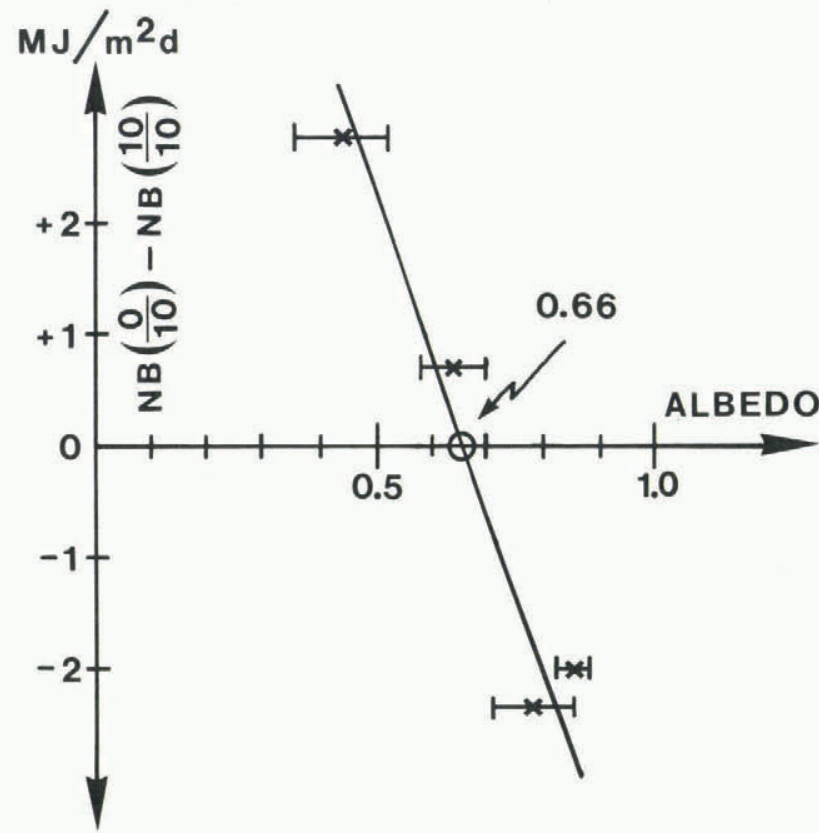

Fig. 1. Difference in net radiation for clear sky and covered sky plotted against albedo. Bars give the estimated range of variations in albedo. Values taken from Ambach (1977[a], p. 22, table 5) and Ambach and Markl (1983, p. 29, fig. 12).

albedo and negative at high albedo. At $a \approx 0.66$, the difference is zero. If the relation between the net radiation balance NB and the cloudiness $w$ is expressed as

$$
\delta N B=B \delta W
$$

the following characteristic values $\beta$ are obtained for different values of the albedo a from Table I and Figure 1:

for dry snow surfaces (EGIG 1967):

$$
a=0.85 ; \quad B=+0.20 \frac{M J m^{-2} d^{-1}}{1 / 10 \text { cloud }} ;
$$

for melting old snow surfaces:

$$
a \approx 0.70 ; \quad \beta \approx 0 ;
$$

for ice surfaces (EGIG 1959):

$$
a=0.44 ; \quad B=-0.28 \frac{\mathrm{MJ} \mathrm{m}^{-2} \mathrm{~d}^{-1}}{1 / 10 \mathrm{cloud}} .
$$

In order to specify the albedo at the equilibrium line during the ablation season, we must take into account that the surface layer may be a melting old snow layer or alternatively a melting superimposed ice layer. Melt water coming from an old snow layer here in general is completely trapped as superimposed ice which will melt again in the course of the ablation period. According to section 4.2 the duration of ablation from an old snow surface and that from a superimposed ice layer have the ratio of $2: 1$ yielding a weighted mean value $\bar{\beta}$ with $\beta=0$ for melting old

snow $(a=0.70)$ and $\beta=-0.28 \frac{\mathrm{MJ} \mathrm{m}^{-2} \mathrm{~d}^{-1}}{1 / 10 \mathrm{cloud}}$ for ice

$(\mathrm{a}=0.44):$

$\bar{\beta}=\frac{2 \beta(\text { snow })+\beta(\text { ice })}{3}=-0.093 \frac{M^{-2} \mathrm{~d}^{-1}}{1 / 10 \mathrm{cloud}}$.

The numerical correlation between changes in cloudiness $\delta w(1 / 10)$ and in net radiation balance $\delta N B$ is given by Equation (6):

$$
\delta N B=-0.093 \delta \mathrm{W} \mathrm{MJ} \mathrm{m}^{-2} \mathrm{~d}^{-1} \text {. }
$$

Equation (8) can be used for calculating the effect of a change in cloudiness on the net radiation balance averaged over the ablation season at the equilibrium line.

\section{SENSIBLE HEAT FLUX AND HEAT TRANSFER COEFFICIENT}

The sensible heat flux $\mathrm{H}_{S}$ is frequently expressed by using the heat transfer coefficient $\alpha$ :

$$
H_{S}=\alpha\left(T_{a}-T_{0}\right)
$$

where $T_{a}$ and $T_{0}$ are the mean air temperature and the surface temperature respectively. Comparison of this expression with Prandtl's formula for adiabatic layering shows $\alpha$ to be proportional to the shear velocity, and thus dependent on the wind velocity and the roughness parameter. This shows that $\alpha$ is not a microclimatological constant.

For a period of $38 \mathrm{~d}$, the sensible heat flux $\mathrm{H}_{\mathrm{S}}$ was calculated for a melting ice surface, using Prandtl's formula and allowing for the non-adiabatic layering (series measured in EGIG 1959). A mean value of $\mathrm{H}_{\mathrm{S}}=3.1 \mathrm{M} \mathrm{m}^{-2} \mathrm{~d}^{-1}$ (Ambach, 1977[a], p. 41, table $9 b)$ is obtained with the roughness parameter $z_{0}=2.21 \times 10^{-3} \mathrm{~m}$ and the shear velocity $u_{x}=0.44 \mathrm{~m} \mathrm{~s}^{-1}$ (Ambach, 1977[b], p. 17, fig. 5b). Both quantities were obtained from the logarithmic wind profile (Fig. $2)$. The mean value of the air temperature at $187 \mathrm{~cm}$ altitude is $1.8^{\circ} \mathrm{C}$ in the ablation period under observation (Ambach, 1977[a], p. 41, table 9b). With $T_{0}=0^{\circ} \mathrm{C}, T_{a}=1.8^{\circ} \mathrm{C}$, and $\mathrm{H}_{S}=3.1 \mathrm{MJ} \mathrm{m}^{-2} \mathrm{~d}^{-1}, \alpha$ is calculated from Equation (9) to be $1.72 \mathrm{MJ} \mathrm{m}^{-2} \mathrm{~d}^{-1} \mathrm{~K}^{-1}$ which agrees with the value reported by Kuhn (1979).

The heat transfer coefficient for a snow surface must be calculated separately owing to the different roughness parameter. Under otherwise equal conditions, with different shear velocities, the relation

$$
\frac{H_{S} \text { (snow) }}{H_{S} \text { (ice) }}=\frac{u_{+} \text {(snow) }}{u_{+} \text {(ice) }}
$$

is valid. Hence

$$
\frac{\alpha(\text { snow })}{\alpha(\text { ice })}=\frac{u_{+} \text {(snow) }}{u_{+}(\text {ice })}
$$



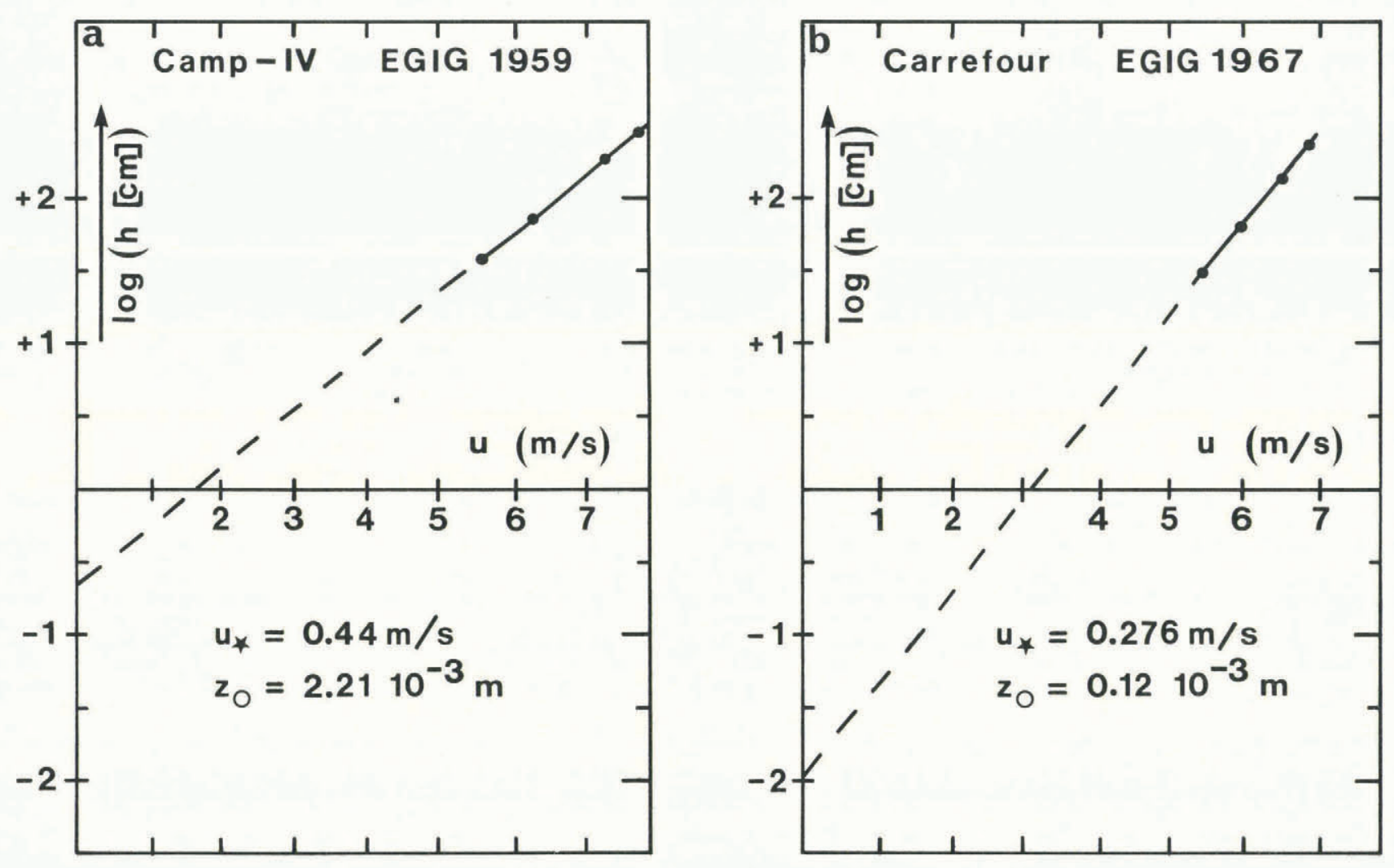

Fig. 2. Mean wind profizes for the entire duration of measurements

(a) EGIG 1959, mainly ice surface

(b) EGIG 1967, snow surface only

according to Ambach (197?[b], p. 17, fig. 5).

with $u_{+}$(snow) $=0.276 \mathrm{~m} \mathrm{~s}^{-1}, u_{+}$(ice) $=0.440 \mathrm{~m} \mathrm{~s}^{-1}$ (Fig. 2) and $\alpha($ ice $)=1.72 \mathrm{MJ}^{-2} \mathrm{~d}^{-1} \mathrm{~K}^{-1}$, we obtain the heat transfer coefficient $\alpha=1.08 \mathrm{MJ} \mathrm{m}^{-2} \mathrm{~d}^{-1} \mathrm{~K}^{-1}$ characteristic of a snow surface. Precisely, this value is valid only for a wind velocity of $u=$ $7 \mathrm{~m} \mathrm{~s}^{-1}, 2 \mathrm{~m}$ above ground, as was measured in this series (expressed in round numbers, cf. Ambach, 1977[b], p. 16, fig. 3).

According to section 4.2 , for two-thirds of the ablation period at the equilibrium line there will be an old snow surface, and for one-third of the time the surface will be superimposed ice. The sensible heat flux under these assumptions may thus be expressed by a weighted mean value $\alpha$, covering the total ablation season

$$
\bar{\alpha}=\frac{2 \alpha(\text { snow })+\alpha(\text { ice })}{3}=1.29 \mathrm{MJ} \mathrm{m}^{-2} \mathrm{~d}^{-1} \mathrm{~K}^{-1} \text {. }
$$

Equation (9) and $T_{0}=0^{\circ} \mathrm{C}$ therefore yield the following relation between change of the sensible heat flux $\delta H_{S}$ and the change in air temperature $\delta T_{a}$ :

$$
\delta H_{S}=1.29 \mathrm{~d}_{\mathrm{a}} M J \mathrm{~m}^{-2} \mathrm{~d}^{-1} \text {. }
$$

Equation (13) permits calculation of the change in sensible heat flux caused by a variation in temperature at the equilibrium line.

\section{HEAT BALANCE}

4.1. Heat balance of snow and ice surfaces

The balance equation takes the following form, positive terms being energy sources, negative terms being energy sinks

$$
\pm N B \pm H_{S} \pm H_{L} \pm H_{C} \pm H_{M}=0
$$

where the terms represent the net radiation balance, the flux of sensible heat, the flux of latent heat, the heat of conduction, and the heat of melt.

The series of measurements from EGIG 1967 gives the heat balance for a prevailingly dry snow surface from 15 May to 27 July 1967 . The mean value of albedo over the entire period of measurement is 0.85 for an undisturbed surface. Traces of melting were observed only on eight days. The albedo on these days dropped to a minimum of 0.73 (Ambach and Mark1, 1983, p. 22, fig. 5).

Table II lists the mean values of the heat balance components for the whole period of measurement. Theoretically, the balance figure must be zero (instead of $\left.+0.3 \mathrm{MJ} \mathrm{m}^{-2} \mathrm{~d}^{-1}\right)$. This discrepancy is due to

TABLE II. MEAN VALUES OF THE COMPONENTS OF THE HEAT BALANCE $\left(M^{-2} \mathrm{~m}^{-2} \mathrm{~d}^{-1}\right), 15$ MAY -27 JULY 1967 ( $7 \mathrm{~d}$, EGIG 1967, ALBEDO $=0.85$, WIND VELOCITY: $\bar{u}(2 \mathrm{~m})=$ $7 \mathrm{~m} \mathrm{~s}^{-1}$, AIR TEMPERATURE: T $(2 \mathrm{~m})=-6.3^{\circ} \mathrm{C}$, VAPOUR PRESSURE: $\overline{\mathrm{e}}(2 \mathrm{~m})=3.2 \mathrm{mbar}$, CLOUDINESS: $\overline{\mathrm{w}}=4.7 / 10$ (Ambach and Mark1, 1983, p. 61, table 1ib)

$\begin{array}{ccc}\begin{array}{c}\text { Energy sources } \\ M J ~ \mathrm{~m}^{-2} \mathrm{~d}^{-1}\end{array} & \begin{array}{c}\text { Energy sinks } \\ M J \mathrm{~m}^{-2} \mathrm{~d}^{-1}\end{array} & \begin{array}{c}\text { Balance } \\ M J \mathrm{~m}^{-2} \mathrm{~d}^{-1}\end{array} \\ \mathrm{SW}=+30.0 & \mathrm{SW}=-25.5 & \mathrm{SB}=+4.5 \\ \mathrm{LW}=+19.9 & \mathrm{LW}=-24.0 & \mathrm{LB}=-4.1 \\ H_{S}=+1.3 & H_{\mathrm{L}}=-1.0 & \mathrm{H}_{\mathrm{S}}+H_{\mathrm{L}}=+0.3 \\ & H_{C}=-0.4 & H_{C}=-0.4 \\ H_{M}=-0.0 & H_{M}=0.0 \\ \Sigma=+51.2 & \Sigma=-50.9 & \Sigma=+0.3\end{array}$


errors of measurement. The error is $<1 \%$ in relation to the sum of energy sources.

The EGIG 1959 series of measurement is characterized by strongly changing albedo, since the surface changed from new snow to old snow and ice. It is therefore meaningful that the components should be given in sections covering periods with characteristic surfaces (Table III). The balance sum yields the theoretical value zero, $H_{M}$ being determined from the

TABLE III. MEAN VALUES OF THE COMPONENTS OF HEAT BALANCE (MJ m $\mathrm{m}^{-2} \mathrm{~d}^{-1}$ ) FOR VARIOUS SURFACES, EGIG 1959 (Ambach and Mark1, 1977[a], p. 41, table 9a-c)

(a) 01d snow surface, period: 26 May -23 June 1959 $(29 \mathrm{~d})$, al bedo $=0.70, \overline{\mathrm{T}}(187 \mathrm{~cm})=1.9^{\circ} \mathrm{C}, \overline{\mathrm{u}}(191 \mathrm{~cm})$ $=7.1 \mathrm{~m} \mathrm{~s}^{-1}, \bar{e}(187 \mathrm{~cm})=4.31 \mathrm{mbar}$

$\begin{array}{llr}\begin{array}{c}\text { Energy sources } \\ \text { MJ } \mathrm{m}^{-2} \mathrm{~d}^{-1}\end{array} & \begin{array}{c}\text { Energy sinks } \\ M J ~ \mathrm{~m}^{-2} \mathrm{~d}^{-1}\end{array} & \begin{array}{c}\text { Balance } \\ M J \mathrm{~m}^{-2} \mathrm{~d}^{-1}\end{array} \\ \mathrm{SW}=+26.3 & \mathrm{SW}=-18.3 & +8.0 \\ \mathrm{LW}=+22.1 & \mathrm{LW}=-25.6 & -3.5 \\ H_{S}=+1.8 & H_{\mathrm{L}}=-2.0 & -0.2 \\ & H_{C}=-1.3 & -1.3 \\ & H_{M}=-3.0 & -3.0 \\ \Sigma=+50.2 & \Sigma=-50.2 & \Sigma= \pm 0.0\end{array}$

(b) Ice surface, period: 24 June -7 July 1959,12 July - 29 July 1959, 2 August -7 August 1959 (38 d), albedo $=0.44, \overline{\mathrm{T}}(187 \mathrm{~cm})=1.8^{\circ} \mathrm{C}, \overline{\mathrm{u}}(191 \mathrm{~cm})$ $=7.4 \mathrm{~m} \mathrm{~s}^{-1}, \bar{e}(187 \mathrm{~cm})=5.77 \mathrm{mbar}$

\begin{tabular}{llr}
$\begin{array}{c}\text { Energy sources } \\
\text { MJ m } \mathrm{m}^{-2} \mathrm{~d}^{-1}\end{array}$ & $\begin{array}{c}\text { Energy sinks } \\
\text { MJ m } \mathrm{m}^{-2} \mathrm{~d}^{-1}\end{array}$ & $\begin{array}{c}\text { Balance } \\
M J \mathrm{~m}^{-2} \mathrm{~d}^{-1}\end{array}$ \\
$\mathrm{SW}=+24.3$ & $\mathrm{SW}=-10.8$ & +13.5 \\
$\mathrm{LW}=+23.7$ & $\mathrm{LW}=-27.3$ & -3.6 \\
$H_{S}=+3.1$ & $H_{\mathrm{L}}=-1.2$ & +1.9 \\
& $H_{C}=-1.0$ & -1.0 \\
& $H_{M}=-10.8$ & -10.8 \\
$\Sigma=+51.1$ & $\Sigma=-51.1$ & $\Sigma= \pm 0.0$ \\
\hline
\end{tabular}

(c) New snow surface, period: 8 July -11 July 1959, 30 July -1 August 1959 (7 d), albedo = 0.70, $\bar{T}(187 \mathrm{~cm})=-0.3^{\circ} \mathrm{C}, u(191 \mathrm{~cm})=6.0 \mathrm{~m} \mathrm{~s}^{-1}, \overline{\mathrm{e}}(187 \mathrm{~cm})$ $=5.11 \mathrm{mbar}$

$\begin{array}{llr}\begin{array}{c}\text { Energy sources } \\ M J \mathrm{~m}^{-2} \mathrm{~d}^{-1}\end{array} & \begin{array}{c}\text { Energy sinks } \\ \text { MJ m } \mathrm{m}^{-2} \mathrm{~d}^{-1}\end{array} & \begin{array}{c}\text { Balance } \\ M J ~ \mathrm{~m}^{-2} \mathrm{~d}^{-1}\end{array} \\ \mathrm{SW}=+22.9 & \mathrm{SW}=-16.0 & +6.9 \\ \mathrm{LW}=+22.8 & \mathrm{LW}=-27.0 & -4.2 \\ H_{S}=+1.9 & H_{\mathrm{L}}=-1.9 & \pm 0.0 \\ & H_{C}=-0.9 & -0.9 \\ H_{M}=-1.8 & -1.8 \\ \Sigma=+47.6 & \Sigma=-47.6 & \Sigma= \pm 0.0\end{array}$

balance equation. For control see Ambach (1977[a], p. 41-42, table 9). Furthermore, graphical comparisons have been made for the sections with snow and ice surfaces respectively as regards the following components: $S B, L B, H_{S}, H_{L}, H_{C}$ and $H_{M}$ (Fig. 3). Snow surfaces receive much less heat for melting than ice surfaces. The energy $\mathrm{H}$ consumed in heating ice is about $1 \mathrm{MJ} \mathrm{m}^{-2} \mathrm{~d}^{-1}$ changing only slowly during the entire period. The fluxes of sensible heat and latent heat $\left(\mathrm{H}_{S}, \mathrm{H}_{\mathrm{L}}\right)$ show considerable fluctuations owing to changing microclimatological conditions, the amounts, however, being only of secondary importance for the melting energy. The essential component is the shortwave radiation balance $\mathrm{SB}$, which shows a correlation with the melting energy $H_{M}$.
SB

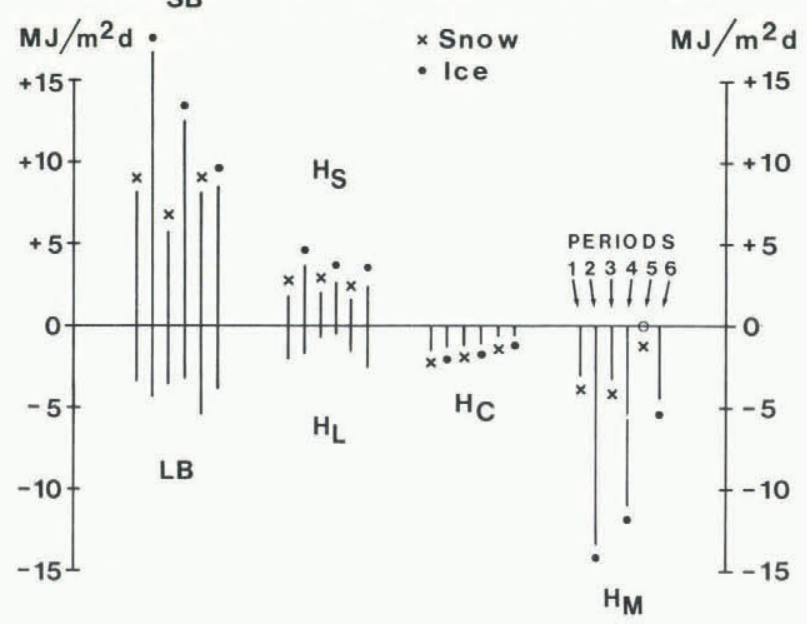

Fig. 3. Components of heat balance given for various periods (cf. Table IV). $S B=$ short-wave radiation balance, $L B=$ long-wave radiation balance, $H_{S}=$ sensible heat flux, $H_{L}=$ latent heat flux, $H_{C}=$ conductive heat flux, $H_{M}=$ heat of melting.

For studying the relation between $S B$ and $H_{M}$, a graph was made for six sub-periods with $\mathrm{H}_{M}$ as a function of $S B$ (Fig. 4). In addition, Figure 4 shows the value of $S B$ plotted for $H_{M}=0$ for the period of EGIG 1967 (period 7, Table IV). The relation between SB and $\mathrm{H}_{M}$ according to Figure $4 \mathrm{can}$ be characterized as follows:

The relation may be approximated by a straight line independent of the situation (snow surface or ice surface). The straight line runs partially outside the error limit, which for each radiation flux, short-wave incoming and short-wave reflected radiation, has been assumed to lie within $2 \%$. This means that the sum of $\mathrm{LB}+\mathrm{H}_{S}+\mathrm{H}_{L}+\mathrm{H}_{C}$ determined by micrometeorological quantities, is only approximately constant. Period 5 does not comply with this requirement. In this case, very strong evaporation is combined with a strong negative value of long-wave radiation balance.

The slope of regression line is $\Delta H_{M} / \triangle S B=1.11$. If the slope were unity this would mean that changes in $S B$ were equivalent to changes in $\mathrm{H}_{M}$.

The correlation between $S B$ and $H_{M}$ corresponds to a threshold function, the threshold being $\mathrm{SB}^{+}=4.5 \mathrm{MJ} \mathrm{m}^{-2} \mathrm{~d}^{-1}$; a value which can be taken from Figure 4 as being the point of intersection with the $S B$ axis. For $S B<\mathrm{SB}^{+}$, the amount of $\mathrm{SB}$ is used for compensating the energy sink LB + $+\mathrm{H}_{S}+\mathrm{H}_{L}+\mathrm{H}_{C}$. For values of $\mathrm{SB}>\mathrm{SB}^{+}$, the difference $\triangle S B=S B-S B^{+}$is used entirely for melting.

This result is of significance in so far as ice or snow ablation by melting may be approximately determined from the easily measured quantity SB, also useful for estimating ablation for specific sites. This simple method can be applied only if the sum $\mathrm{SB}+\mathrm{H}_{S}+\mathrm{H}_{1}+\mathrm{H}_{\mathrm{C}}$ is approximately constant, the threshold $\mathrm{SB}^{+}$being known. In periods of extremely low or high cloudiness, or if the micrometeorological quantities are extreme, this numerical condition is not satisfied (cf. period 5 , Fig. 4).

The value of $\triangle H_{M} / \triangle S B=1.11$ furthermore indicates that higher $S B$ values in general mean additional energy for melting is available. The energy for melting provided by $\triangle S B$ is increased by other energy sources by about $11 \%$. This difference may be allowed for by reducing the energy sinks by $11 \%$.

For further discussion, the threshold function is 
TABLE IV. MICROMETEOROLOGICAL DATA FOR SPECIFIC PERIODS, DATA REFERRING TO FIG. 4 (Ambach 1977[a], p. 41, table 9a; p. 45, table 13a-e; Ambach and Markl, 1983, p. 58, table 8)

$\begin{array}{cccccccc}\begin{array}{c}\text { Period } \\ \text { no. }\end{array} & \text { Duration } & \begin{array}{c}\text { Length } \\ \mathrm{d}\end{array} & \begin{array}{c}\text { Surface } \\ \text { Albedo }\end{array} & \begin{array}{c}T(187 \mathrm{~cm}) \\ { }^{\circ} \mathrm{C}\end{array} & \begin{array}{c}u(191 \mathrm{~cm}) \\ \mathrm{m} \mathrm{s}^{-1}\end{array} & \begin{array}{c}e(187 \mathrm{~cm}) \\ \mathrm{mbar}\end{array} \\ 1 & 26 \text { May-23 June 1959 } & 29 & \text { snow } & 0.70 & +1.9 & 7.1 & 4.31 \\ 2 & 24 \text { June-7 July 1959 } & 14 & \text { ice } & 0.43 & +2.5 & 8.9 & 5.69 \\ 3 & \text { 8 July -11 July 1959 } & 4 & \text { snow } & 0.74 & -0.3 & 6.4 & 5.37 \\ 4 & 12 \text { July -29 July 1959 } & 18 & \text { ice } & 0.43 & +1.9 & 6.4 & 6.01 \\ 5 & \text { 30 July -1 August 1959 } & 3 & \text { snow } & 0.64 & -0.3 & 6.8 & 4.73 \\ 6 & \text { 2 August-7 August 1959 } & 6 & \text { ice } & 0.54 & +0.2 & 6.9 & 5.25 \\ 7 & 15 \text { May-27 July 1967 } & 74 & \text { snow } & 0.85 & -6.6^{*} & 5.8^{*} & 3.20^{*}\end{array}$

* For period 7 the values in the last three columns are for $\bar{T}(200 \mathrm{~cm}), \bar{u}(230 \mathrm{~cm})$, and $\bar{e}(200 \mathrm{~cm})$

divided into the regions $\mathrm{I}$ and II (Fig. 4). In the ablation period with strong ice or snow melting, the energy balance satisfies the conditions of region II, i.e. the short-wave radiation balance $S B$ is partly used for compensating the energy sink $L B+\mathrm{H}_{S}+\mathrm{H}_{\mathrm{L}}$ $+\mathrm{H}_{C}$ and partly used for energy of melting $\mathrm{H}_{M}$. At the end of the ablation period we reach a situation when $S B=S B^{+}$. As the season progresses further, $S B$ still decreases in region $I$. As there is no melting in region $\mathrm{I}$, the point of state shifts along the $\mathrm{SB}$ axis towards zero. In this region, the energy balance is valid in the form of $\mathrm{SB}+\mathrm{LB}+\mathrm{H}_{S}+\mathrm{H}_{\mathrm{L}}+\mathrm{H}_{C}$ $=0$, with $\mathrm{SB}<\mathrm{SB}^{+}$. If zero is reached in the polar night $(S B=0)$, energy sources and energy sinks compensate without any contribution from the short-wave radiation balance, the energy balance being $L B+$

$+\mathrm{H}_{S}+\mathrm{H}_{\mathrm{L}}+\mathrm{H}_{\mathrm{C}}=0$.

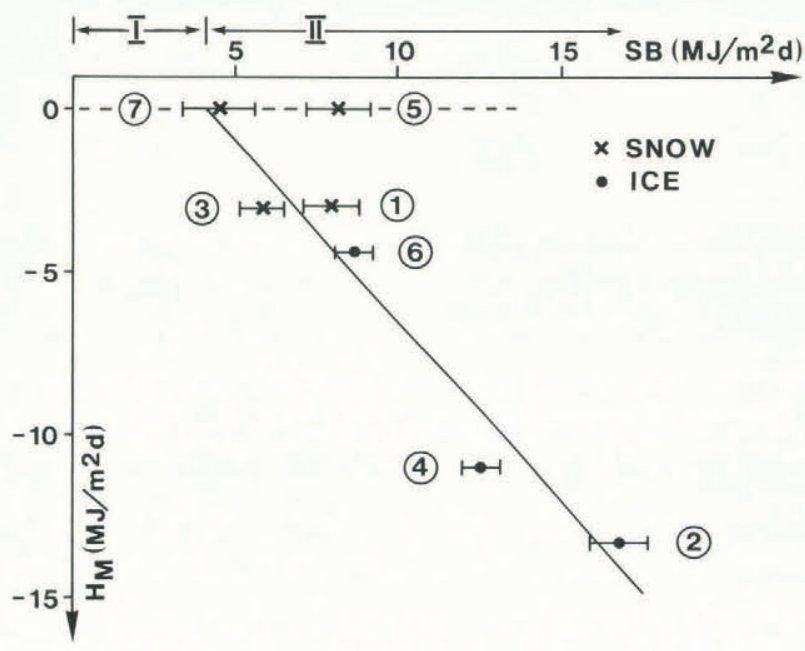

Fig. 4. Heat of melting $\left(H_{M}\right)$ versus short-wave radiation balance (SB) for seven periods (cf. Table IV). $I=$ range without any melting, $I I=$ range with melting. The bars give the error limits for $S B$.

\subsection{Formation of superimposed ice}

In the region near the equilibrium line, the formation of superimposed ice is of decisive importance for mass balance and for energy balance (Ambach, 1963; de Quervain, 1969). Superimposed ice forms from melt water coming from the old snow layer and collecting at the impermeable cold ice surface where it freezes.

The heat of melting liberated is thus conducted into the underlying ice. The energy transformation under the condition of total formation of superimposed ice is shown in Figure $5 b . Q_{0}$ is the energy per unit area required to melt the old snow layer $h_{0}$ with no superimposed ice forming (Fig. $5 a$ ), $Q_{1}+Q_{2}$ is the energy per unit area necessary for melting the old snow layer $h_{1}$ plus the superimposed ice layer $h_{2} \cdot Q_{1}+Q_{2}>Q_{0}$ is valid since the temperature of the ice body rises as the formation of superimposed ice progresses. This energy must be expended additionally. The liberated heat of melting and the energy used for heating the ice by heat conduction are equal. If the total melt water from the old snow layer is consolidated as superimposed ice, then $Q_{0}=Q_{2}$ and $Q_{1}=Q_{3}$ (Fig. $5 \mathrm{~b}$ ). Superimposed ice formation has been calculated repeatedly for different initial and boundary conditions (Ambach 1963; de Quervain 1969). With representative values of the initial temperature $\left(-10^{\circ} \mathrm{C}\right)$ and of the temperature gradient in the depth profile $(1 \mathrm{~K} / \mathrm{m}), 0.4$ to $1.4 \mathrm{~cm}$ of superimposed ice per day will form during the ablation period (Ambach, 1963, p. 169, fig. 68).

The formation of superimposed ice leads to a change from a melting old snow surface to a surface of melting superimposed ice during the ablation season. This situation has a marked effect on the energy balance, as the albedo and the roughness parameter are changed considerably by that fact.

(a)
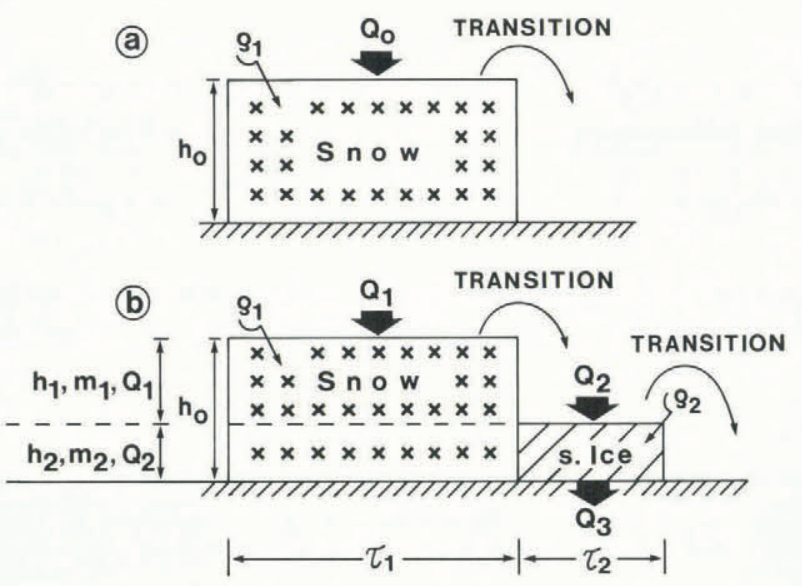

Fig. 5. Formation of superimposed ice in a schematic diagram. $Q=$ heat $\left(M J m^{-2}\right), m=$ water equivalent

$\left(\mathrm{kg} \mathrm{m}^{-2}\right), h=\operatorname{depth}(\mathrm{m}), \tau=$ number of days

(a) without formation of superimposed ice

(b) with full formation of superimposed ice. 
In the region of stake BK 7 (1241 m a.s.1.) lying approximately at the equilibrium line, all the melt water from the old snow presumably turns into superimposed ice. The minimum snow temperature there $\left(-8^{\circ} \mathrm{C}\right)$ was measured before the ablation season set in (Ambach, 1963, p. 160, fig. 64), the minimum ice temperature at $2 \mathrm{~m}$ depth under the ice surface being $-10^{\circ} \mathrm{C}$. The snow density in the vertical profile was between 300 and $400 \mathrm{~kg} / \mathrm{m}^{3}$.

Before describing the effects which the superimposed ice has on the energy balance during the ablation season, the duration of the intervals with a snow surface and an ice surface must be known. The calculation is made as follows, the density of old snow $\rho_{1}=300 \mathrm{~kg} / \mathrm{m}^{3}$ and that of superimposed ice $\rho_{2}=900 \mathrm{~kg} / \mathrm{m}^{3}$. Index 1 refers to the old snow layer and index 2 refers to the newly formed superimposed ice layer (Fig. 5b).

Maximum thickness of the superimposed ice:

For the maximum thickness of the superimposed ice layer $h_{2}$, that may form from the old snow layer $h_{0}$, the following equations are obtained from the conservation of the total mass:

$$
\frac{h_{2}}{h_{0}}=\frac{\rho_{1}}{\rho_{2}}=\frac{1}{3} \text { and } \frac{h_{2}}{h_{1}}=\frac{\rho_{1}}{\rho_{2} \rho_{1}}=\frac{1}{2} \text {. }
$$

$$
\frac{m_{2}}{m_{1}}=\frac{h_{2} \rho_{2}}{h_{1} \rho_{1}}=\frac{\rho_{2}}{\rho_{2}-\rho_{1}}=\frac{3}{2}
$$

Heat of melt:

Transformation of the old snow layer $h_{1}$ into a superimposed ice layer $h_{2}$ and subsequent melting requires energy as follows (Fig. $5 b$ ):

$$
\begin{aligned}
& \frac{Q_{2}}{Q_{1}}=\frac{m_{2}}{m_{1}}=\frac{\rho_{2}}{\rho_{2}-\rho_{1}}=\frac{3}{2}, \\
& \frac{Q_{1}+Q_{2}}{Q_{0}}=\frac{h_{1} \rho_{1}+n_{2} \rho_{2}}{n_{\infty} \rho_{1}}=\frac{5}{3} .
\end{aligned}
$$

Duration of ablation of old snow surface $\tau_{1}$ and of superimposed ice surface $\tau 2$ :

For calculating the number of ablation days with a snow surface and with an ice surface it is necessary to know the energy balance for both surfaces. Thus

$$
\frac{\tau_{2}}{\tau_{1}}=\frac{Q_{2} H_{M}(1)}{Q_{1} H_{M}(2)}
$$

where $H_{M}(1)$ and $H_{M}(2)$ are the heat of melting per day per unit area resulting from the energy balance, the index (1) being valid for a snow surface and the index (2) for an ice surface.

The numerical difference between $H_{M}(1)$ and $H_{M}(2)$ is due to the change in albedo and in roughness parameter resulting from the transition from a snow surface to an ice surface. From the energy balance we obtain the following equation for the heat required for melting (Equation 14):

$$
-H_{M}=+\mathrm{NB}+\mathrm{H}_{S}+\mathrm{H}_{L}+\mathrm{H}_{C}
$$

where $N B, H_{S}, H_{L}$, and $H_{C}$ are the net radiation balance, the sensible heat flux, the latent heat flux, and the conductive heat flux into the ice. For a nonmelting surface $\mathrm{H}_{M}=0$.

Transition of a dry snow surface into the state of melting (1), or into a state of melting of a superimposed ice layer (2), yields the daily energy output $H_{M}(1), H_{M}(2)$ as the difference values $\Delta H_{M}(1)$, $\Delta H_{M}(2)$ from

$$
\Delta H_{M}(1,2)=\Delta N B+\Delta\left(H_{S}+H_{L}\right)+\Delta H_{C}
$$

where $\triangle N B$ means the change in net radiation balance due to the change in albedo, $\Delta\left(H_{S}+H_{L}\right)$ is the change in sensible and latent heat fluxes due to changes of the roughness parameter, and $\Delta \mathrm{H}_{\mathrm{C}}$ the change of the heat conduction in ice, which depends on the change in temperature gradient. If we assume that changes in the albedo $\Delta$ a are of predominant importance in causing changes in the heat of melting $\Delta H_{M}$, we obtain the following approximation averaged over the ablation period

$$
\Delta H_{M}=-G \Delta a \text {. }
$$

For a transition from a dry surface to a melting surface we have $\Delta H_{M}=H_{M}$. For $\Delta a_{1}=0.15$ and $\Delta a_{2}=0.45$ it follows that

$$
\frac{H_{M}(1)}{H_{M}(2)}=\frac{\Delta H_{M}(1)}{\Delta H_{M}(2)}=\frac{\Delta a_{1}}{\Delta a_{2}}=\frac{1}{3} \text {. }
$$

Here, with the onset of melting, the albedo of the dry snow surface was assumed to decrease from 0.85 to $0.70\left(\Delta a_{1}=0.15\right)$ and for a superimposed ice surface it was assumed to decrease from 0.85 to $0.40(\Delta a 2=$ $0.45)$. Equation (23) approximately agrees with the result of section 4.1 , Figure 4 , where

$$
\text { - } \Delta H_{M}=\Delta S B=-G \Delta a
$$

is well satisfied for $\Delta G=0$.

For Equation (19) we thus have

$$
\frac{\tau_{2}}{\tau_{1}}=\frac{\rho_{2}}{\rho_{2}-\rho_{1}} \frac{\Delta a_{1}}{\Delta a_{2}}=\frac{3}{2} \times \frac{1}{3}=\frac{1}{2} .
$$

The ablation period of the superimposed ice layer is therefore $50 \%$ shorter than that of the old snowpack. This difference is due to the low albedo of the ice surface as compared to the snow surface, and is valid even though the mass of the superimposed ice layer is $50 \%$ higher than that of the melted old snow layer (Equation (16)). In an ablation season of $30 \mathrm{~d}$, for example, the old snow surface will exist for $20 \mathrm{~d}$, while an ice surface exists for only $10 \mathrm{~d}$.

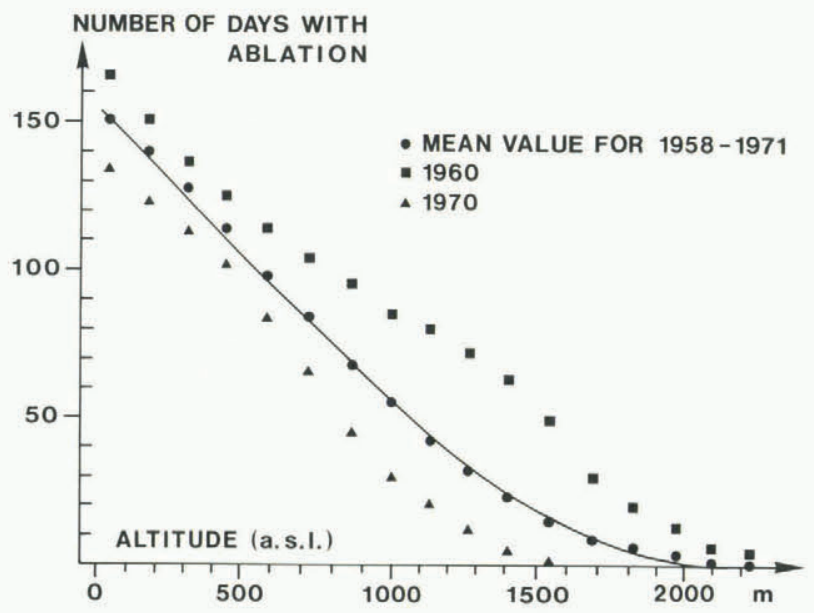

Fig. 6. Number of ablation days $\left(\bar{T}>0^{\circ} \mathrm{C}\right)$ versus altitude calculated from values of air temperature in Jakobshavn station ( $40 \mathrm{~m} \mathrm{a.s.l.)}$ ) and an altitudinal gradient of air temperature of $0.0073 \mathrm{~K} / \mathrm{m}$. 
4.3 Duration of the ablation season

If days having a mean temperature of $\bar{T}>0^{\circ} \mathrm{C}$ are said to be ablation days, their number in the ablation season may be calculated as a function of altitude. This calculation is based on temperature values from the meteorological station on the west coast (Jakobshavn station, $40 \mathrm{~m}$ a.s.1.) and on the temperature gradient in the EGIG profile. Comparison of temperatures from the Jakobshavn station and those from station Camp IV EGIG 1959 during the ablation season 1959 yielded a temperature gradient of $0.73 \mathrm{~K} /$ $100 \mathrm{~m}$ (Ambach, 1977[a], p. 36, fig. 19). Braithwaite (unpublished) pointed out that large glacier regions show horizontal gradients in addition to the vertical gradient $>0.6 \mathrm{~K} / 100 \mathrm{~m}$. From the meteorological records of Jakobshavn station, the number of ablation days as dependent on the altitude were newly calculated for the years 1958 to 1971 (Fig. 6). The resulting minimum, mean, and maximum durations of the ablation season at

TABLE V. MINIMUM, MEAN, AND MAXIMUM DURATIONS OF THE ABLATION SEASON AT VARIOUS ALTITUDES TAKEN FROM FIGURE 6 (ROUNDED VALUES)

\begin{tabular}{crrr} 
& \multicolumn{3}{c}{ Days with ablation } \\
Altitude & Minimum & Mean & Maximum \\
m a.s.1. & d & d & d \\
& & & \\
500 & 100 & 105 & 120 \\
1000 & 30 & 55 & 85 \\
1240 & 15 & 35 & 75 \\
1500 & 2 & 20 & 55 \\
1850 & 0 & 5 & 15
\end{tabular}

Remarks

Camp IV-ËGIG 1959 equilibrium line

Carrefour

EGIG 1967

$500 \mathrm{~m}, 1000 \mathrm{~m}$ (Camp IV-EGIG 1959), $1240 \mathrm{~m}$ (equilibrium line), $1500 \mathrm{~m}$, and $1850 \mathrm{~m}$ (Carrefour-EGIG 1967) are listed in Table $V$ for the indicated length of time. For the equilibrium line at an altitude of $1241 \mathrm{~m}$ a.s.1. (BK 7), 15-75 ablation days are obtained by interpolation, 35 ablation days being obtained from the mean curve. It must, however, be emphasized that the actual number of ablation days is higher than the number here calculated. The reason is that melting takes places at noon even if the air temperature has a daily mean value of $\bar{T}<0^{\circ} \mathrm{C}$. The values of ablation periods given in Figure 5 are to be taken as lower boundary values.

The number of ablation days $\left(T>0^{\circ} \mathrm{C}\right)$ for the series of measurements EGIG 1959 and EGIG 1967 may be taken directly from the $24 \mathrm{~h}$ mean values of air temperature and may be compared with the data taken from Table V. From air temperature measurement the following results are obtained:

for EGIG 1959, 16 May- 8 August 1959 (Ambach, 1963 , p. 268, table 42):

45 ablation days ( 55 ablation days according to Fig. 6).

for EGIG 1967, 20 May - 28 July 1967 (Ambach, 1977[b], p. 20, table 3):

3 ablation days ( 5 ablation days according to Fig. 6).

The figures in parentheses are taken from the mean curve of Figure 6 for $1000 \mathrm{~m}$ a.s.1. (EGIG 1959) and for $1850 \mathrm{~m}$ a.s.1. (EGIG 1967). Statistical studies of temperature values at Jakobshavn station show that the years 1959 and 1967 correspond well with the mean values of the period 1958-1971 (Ambach, 1977[a], p. 61 , fig. 25). The difference of 10 ablation days for EGIG 1959 is understandable as the ablation season at sea-level need not have terminated at the end of the period of measurements ( 8 August 1959).

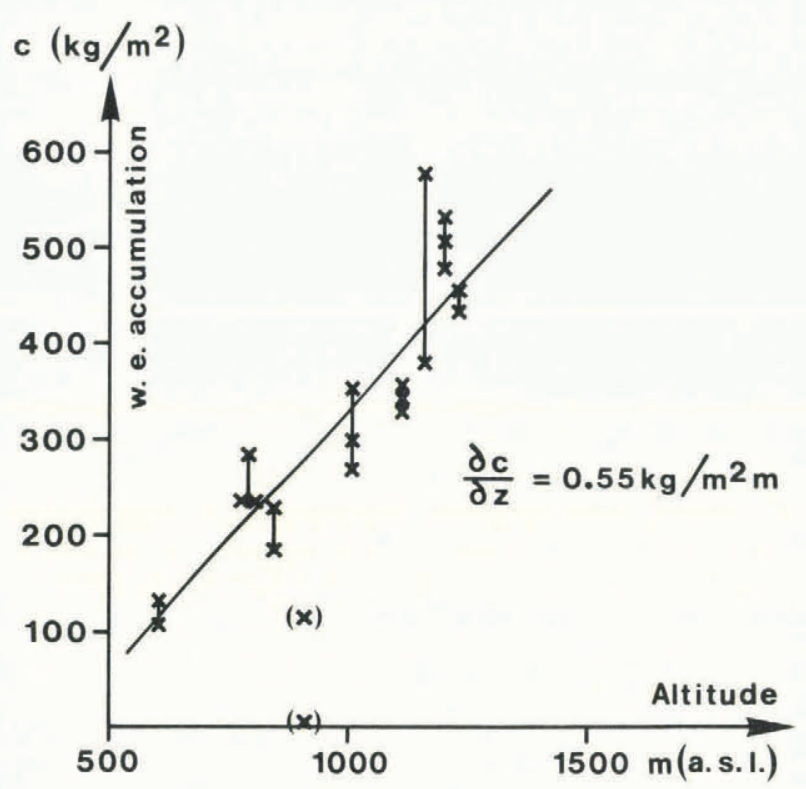

Fig. 7. Winter accumulation in the ablation area measured between $?$ and 20 May 1959 versus altitude. Measured values are extrapolated by the factor $12 / 9=4 / 3$ for the balance year (cf. Ambach, 1963, p. 298, table 53).

\subsection{Winter accumulation}

Depths of snow forming the winter accumulation from August 1958 to May 1959 at altitudes between $612 \mathrm{~m} \mathrm{a.s.1.} \mathrm{(BK} \mathrm{1)} \mathrm{and} 1241 \mathrm{~m} \mathrm{a.s.1.} \mathrm{(BK} \mathrm{7)} \mathrm{were}$ measured during EGIG 1959 (Ambach, 1963, p. 298, table 53). Data were converted into water equivalents using the snow densities at the sites of measurement. In order to extrapolate the water equivalents for the whole balance year 1958/59, the water equivalents were multiplied by the factor of $12 / 9=4 / 3$. Figure 7 shows the extrapolated values of the water equivalent plotted versus altitude, the gradient amounts to $0.55 \mathrm{~kg}$ $\mathrm{m}^{-2} \mathrm{~m}^{-1}$ as being valid in the region below the equilibrium line. Using Kuhn's algorithm in relation to superimposed ice, the effective gradient according to Equation (18) is

$$
\frac{\partial c}{\partial z}=0.55 \times \frac{5}{3}=0.92 \mathrm{~kg} \mathrm{~m}^{-2} \mathrm{~m}^{-1} \text {. }
$$

In the region above the equilibrium line, the gradient of accumulation can be found by pit studies at sites without any run-off. Such pit studies were carried out on the EGIG profile by Benson (1962) at altitudes above $1746 \mathrm{~m}$ a.s.1. and by de Quervain (1969) at Camp VI-EGIG, $1684 \mathrm{~m}$ a.s.1., Carrefour $1850 \mathrm{~m}$ a.s.1., and Milcent $2448 \mathrm{~m}$ a.s.1. Regardless of the fact that the averaged rate of accumulation in pit studies can be obtained over a certain period, the values from those sites need not necessarily represent the condition at the equilibrium line. No accumulation data are available at altitudes between $1241 \mathrm{~m}$ a.s.1. (BK 7) and $1648 \mathrm{~m} \mathrm{a.s.1.} \mathrm{(Camp} \mathrm{VI-EGIG),} \mathrm{which} \mathrm{may} \mathrm{be} \mathrm{im-}$ portant for consideration of the shift of the equilibrium line in response to climatic warming.

\section{CONCLUSIONS}

For applying Kuhn's algorithm to the EGIG profile, special heat-balance quantities at the equilibrium line must be known. The equilibrium line may generally be assumed to be near $1241 \mathrm{~m}$ a.s.1. This altitude results from mass-balance measurements at the EGIG profile. In particular in 1959, at the end of 
the ablation season, it was found that $b_{S}=0$ at the site of BK 7 at $1241 \mathrm{~m} \mathrm{a.s.1.} \mathrm{(Ambach,} \mathrm{1963,} \mathrm{p.} \mathrm{151,}$ fig. 58a). The balance year 1959 represents average conditions with respect to the number of days with ablation (Ambach, 1977[a], p. 61, fig. 25). At BK 7 superimposed ice showed maximum thickness and was found to have melted completely by the end of the ablation season. However, no ice from previous years was ablated.

In 1959 the water equivalent of winter accumulation at BK 7 amounts to $349 \mathrm{~kg} \mathrm{~m}^{-2}$, the snow depth being $0.85 \mathrm{~m}$. The maximum thickness of $0.28 \mathrm{~m}$ of the superimposed ice layer results from Equation (15). The number of days with ablation was $35 \mathrm{~d}$ (Fig. 6 and Table V), consequently the interval during which there was a snow surface 1asts for $23 \mathrm{~d}$ and that with a superimposed ice surface for $12 \mathrm{~d}$ (Equation (24)). The heat consumed for melting both the old snow and the superimposed ice layer results from Equation (18):

$$
349 \mathrm{~kg} \mathrm{~m}^{-2} \times \frac{5}{3} \times 333.2 \times 10^{3} \mathrm{~J} \mathrm{~kg}^{-1}=195 \mathrm{MJ} \mathrm{m}^{-2}
$$

Consequently, a daily energy input of $5.6 \mathrm{MJ} \mathrm{m}^{-2} \mathrm{~d}^{-1}$ is obtained for melting averaged over the period of $35 \mathrm{~d}$. At the equilibrium line, no heat-balance measurements were carried out during EGIG. Only data from the central ablation area at $1013 \mathrm{~m}$ a.s.l. (EGIG 1959) and from the accumulation area at 1850 m a.s.1. (EGIG 1967) are available. Results of EGIG 1967 are assumed to be representative for the dry snow surface without significant melting, those of EGIG 1959 for the melting ice surface. From both studies the proper heat-balance quantities at the equilibrium line are derived for Kuhn's algorithm:

The quantity $\alpha$ (Equation (9)) depends on the shear velocity, which is influenced by the surface roughness and the wind velocity. The shear velocity for the ice surface is taken from EGIG 1959, that for the snow surface from EGIG 1967.

The quantity $\alpha^{\prime}$ (Equation (4)) depends on the surface temperature. The results of EGIG 1959 with surface temperatures at $0^{\circ} \mathrm{C}$ are applied for the whole ablation period at the equilibrium line.

The quantitity $\beta$ (Equation (6)) depends significantly on the albedo. For a wet old snow surface $B \approx 0$, the albedo being 0.66 (Fig. 1). For an ice surface the value of $\beta$ was taken from EGIG 1959.

At the equilibrium 1 ine the ratio of the number of days with a melting snow surface and with melting superimposed ice is 2:1 (Equation (24)). Consequently, the quantities which depend on the type of surface snow or ice $(\alpha, \beta)$, are averaged using the weights $2: 1$. The mean values are (Equations (7) and (12)):

$\bar{\alpha}=\frac{2 \alpha(\text { snow })+\alpha(\text { ice })}{3}=1.29 \mathrm{MJ} \mathrm{m}^{-2} \mathrm{~d}^{-1} \mathrm{~K}^{-1}$,

$\bar{\beta}=\frac{2 \beta(\text { snow })+\beta(\text { ice })}{3}=0.093 \frac{\mathrm{MJ} \mathrm{m}^{-2} \mathrm{~d}^{-1}}{1 / 10 \mathrm{cloud}}$.

The quantity $\alpha^{\prime}$ has the same value for snow and for ice surfaces. Therefore no weighted average need be calculated for this quantity.

The formation of superimposed ice influences significantly the amount of heat necessary for melting the winter accumulation ( $\left.b_{S}=0\right)$. Comparing both conditions, superimposed ice and no superimposed ice, the ratio of the heat for melting the total winter accumulation amounts to $5 / 3$ according to Equation (18).

Assuming Kuhn's algorithm for the calculation of the shift of the equilibrium line (Kuhn, [1981]; Ambach, in press)

$$
\Delta h\left\{\frac{\partial c}{\partial z} \frac{L}{\tau}-\left(\alpha^{\prime}+\alpha\right) \frac{\partial T_{a}}{\partial z}\right\}=\left(\alpha^{\prime}+\alpha\right) \delta T_{a}+\beta \delta W
$$

with the conditions:

$\delta \mathrm{C}=0$ (Reeh and others, 1978)

$\alpha=1.29 \mathrm{MJ} \mathrm{m}^{-2} \mathrm{~d}^{-1} \mathrm{~K}^{-1}$, Equation

$\alpha^{\prime}=0.37 \mathrm{MJ} \mathrm{m}^{-2} \mathrm{~d}^{-1} \mathrm{~K}^{-1}$, Equation

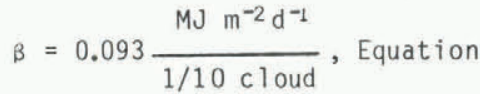

$\frac{\partial c}{\partial z}=0.55 \times \frac{5}{3} \approx 1 \mathrm{~kg} \mathrm{~m}^{-2} \mathrm{~m}^{-1}$, Equation

$\tau=35 \mathrm{~d}(\mathrm{Tab} l \mathrm{e} \mathrm{V})$

and $L=0.3336 \mathrm{MJ} \mathrm{kg}^{-1}$, specific heat of melt, the shift becomes:

$$
\begin{aligned}
& \frac{\Delta h}{\delta T_{a}}=+77 \mathrm{~m} \mathrm{~K}^{-1} \text { at constant cloudiness and } \\
& \frac{\Delta h}{\delta w}=-4 \mathrm{~m} \mathrm{~K}^{-1} \text { at constant temperature. }
\end{aligned}
$$

Discussions on the response of the equilibrium line to climatic disturbances are published elsewhere in detail (Ambach, in press; Ambach and Kuhn, in press). Further effort is necessary to inititate heat-balance investigations in the other regions of the Greenland ice sheet in order to apply Kuhn's algorithm for the entire Greenland ice sheet.

\section{LIST OF SYMBOLS AND UNITS}

$\mathrm{b}_{\mathrm{S}}$

e

$\mathrm{H}_{\mathrm{S}}$

$\mathrm{H}_{\mathrm{L}}$

${ }^{\mathrm{C}}$

$\mathrm{H}_{\mathrm{M}}$

$h_{0}, h_{1}$, thickness of layers of snow

$h_{2} \quad\left(h_{0}, h_{1}\right)$ and of superimposed ice (h2)

$\Delta \mathrm{h} \quad$ altitudinal shift of the equilibrium line

specific heat of melt

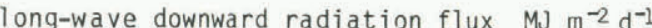
albedo

$\mathrm{kg} \mathrm{m}^{-2} \mathrm{a}^{-1}$ $\mathrm{kg} \mathrm{m}^{-2} \mathrm{a}^{-1}$ $\mathrm{kg} \mathrm{m}^{-2} \mathrm{a}^{-1}$ mbar Mu $m^{-2} d^{-1}$ Mu $m^{-2} d^{-1}$ MJ $m^{-2} d^{-1}$ MJ $m^{-2} d^{-1}$ MJ $m^{-2} d^{-1}$ MJ $\mathrm{kg}^{-1}$ 


\begin{tabular}{|c|c|c|c|}
\hline B & long-wave radiation balance & MJ $m^{-2} d^{-1}$ & \\
\hline $\mathrm{W}$ & $\begin{array}{l}\text { long-wave radi } \\
\text { (downward or u }\end{array}$ & $\mathrm{m} \mid \mathrm{J} \mathrm{m}^{-2} \mathrm{~d}^{-1}$ & $\begin{array}{l}5 \\
\text { satz } \\
\text { land- }\end{array}$ \\
\hline , $m_{2}$ & $\begin{array}{l}\text { mass of snow }\left(m_{1}\right) \text { and of ice } \\
\left(m_{2}\right) \text { per unit area }\end{array}$ & $\mathrm{kg} \mathrm{m}^{-2}$ & $\begin{aligned} e i \\
\text { Amba }\end{aligned}$ \\
\hline B & net radiation balance & Mu $m^{-2} d^{-1}$ & $\begin{array}{l}\text { Atmosphäre und Kl imaänderung: mögliche Auswirkungen } \\
\text { auf den grönländischen Eisschild. Wetter und Leben, } \\
\text { Jahrg. } 32 \text {, Ht. 3, p. 135-42. }\end{array}$ \\
\hline${ }_{Q_{2}} Q_{1}$, & heat per unit area & Mu $m^{-2}$ & $\begin{array}{l}\text { Ambach, W. In press. Climatic shift of the equilibrium } \\
\text { line - Kunn's concept applied to the Greenland ice } \\
\text { cap. Annals of Glaciology, Vol. } 6 \text {. }\end{array}$ \\
\hline 3 & onduction per $u$ & $M J m^{-2}$ & $\begin{array}{l}\text { gradi- } \\
\text { for }\end{array}$ \\
\hline B & $\mathrm{n}$ bal & $M J m^{-2} d^{-1}$ & mo \\
\hline $\mathrm{B}^{+}$ & $\begin{array}{l}\text { threshold of SB for condition } \\
\text { of melt }\end{array}$ & $M J m^{-2} d^{-1}$ & $\begin{array}{l}\text { intand, } \\
\text { in }\end{array}$ \\
\hline W & $\begin{array}{l}\text { ation flux } \\
\text { vard) }\end{array}$ & $\mathrm{mU} \mathrm{m}^{-2} \mathrm{~d}^{-1}$ & $\begin{array}{l}\text { sheet. } \\
\text { s2. }\end{array}$ \\
\hline${ }^{T}, \mathrm{~T}_{\mathrm{T}}^{\mathrm{T}}$, & $\begin{array}{l}\text { ature of the air }\left(T, T_{a}\right) \\
\text { the surface }\left(T_{0}\right)\end{array}$ & $\mathrm{K},{ }^{\circ} \mathrm{C}$ & $\begin{array}{l}\text { Benson, } \mathrm{C} \\
\text { and fir } \\
\text { and Perm }\end{array}$ \\
\hline & wine & $\mathrm{m} \mathrm{s}^{-1}$ & ana \\
\hline$u_{+}$ & she & $m s^{-1}$ & \\
\hline & $\mathrm{clou}$ & 1 & $\begin{array}{r}\text { Kuh } \\
\text { c }\end{array}$ \\
\hline & a & $\mathrm{m}$ & , Vol. 22, No. 81, \\
\hline$z_{0}$ & pa & $\mathrm{m}$ & $\begin{array}{l}\text { ers. }[t \\
\text { e. Ass }\end{array}$ \\
\hline & ent & MJ $\mathrm{m}$ & \\
\hline & $\mathrm{fac}$ & MJ m & 1, $\begin{array}{l}s y \\
g e\end{array}$ \\
\hline & $\mathrm{fac}$ & J $n$ & \\
\hline$\rho_{2}$ & $\begin{array}{l}\text { ere }(\varepsilon+(w)) \text { and of the su } \\
\text { long-wave radiation as a } \\
\text { iction of cloudiness } \\
\text { sity of snow }\left(\rho_{1}\right) \text { and of } \\
\left(\rho_{2}\right)\end{array}$ & s & $\begin{array}{l}\text { adgrenze und } \\
\text { esbericht } \\
3 \text {. } \\
\text { renze auf } \\
\text { scherkunde } \\
0 \text {, } 241-54 . \\
\text { Arbeiten } \\
\text { nland- } \\
\text { Gronland }\end{array}$ \\
\hline$\sigma$ & 1tzmann constant & MJ $\mathrm{m}$ & ser om \\
\hline $\begin{array}{c}\tau, \tau_{1}, \\
\tau_{2}\end{array}$ & $\begin{array}{l}\text { number of da } \\
\text { snow }\left(\begin{array}{ll}\tau & 1\end{array}\right)\end{array}$ & 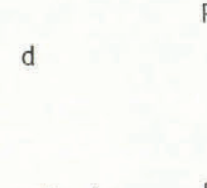 & $\begin{array}{l}\text { al } \\
\text { irts I } \\
\text { der. }\end{array}$ \\
\hline \multicolumn{3}{|c|}{$\begin{array}{l}\text { Ambach, W. 1963. Untersuchungen zum Energieumsatz in } \\
\text { der Ablationszone des grönländischen Inlandeises } \\
\text { (Camp IV-EGIG, 69 } 40^{\circ} 05^{\prime \prime} \mathrm{N}, 49^{\circ} 37^{\prime} 58^{\prime \prime} \mathrm{W} \text { ). Meddelelser } \\
\text { om Gronland, Bd. 174, Nr. } 4 \text {. } \\
\text { Ambach, W. 1974. The influence of cloudiness on the } \\
\text { net radiation balance of a snow surface with high } \\
\text { albedo. Journal of Glaciology, Vol. 13, No. } 67 \text {, } \\
\text { p. 73-84. }\end{array}$} & $\begin{array}{l}\text { Reeh, N., and others. 1978. Secular trends of accumu- } \\
\text { lation rates at three Greenland stations, by N. Reeh, } \\
\text { H.B. Clausen, W. Dansgaard, N. Gundestrup, } \\
\text { C.U. Hammer, and S.J. Johnsen. Journal of Glaciology, } \\
\text { Vol. 20, No. 82, p. } 27-30 \text {. } \\
\text { Weidick, A. 1975. Estimates on the mass balance } \\
\text { changes of the inland ice since Wisconsin-Weichsel. } \\
\text { Gronlands Geologiske Undersøgelse. Rapport Nr. 68. }\end{array}$ \\
\hline
\end{tabular}

